[6] "Razbyraemsya s novыmy arkhytekturnыmy komponentamy v Android," / Bloh kompanyy Google / Khabrakhabr. [Online]. Available: https://habrahabr.ru/company/google/blog/330208/. [Accessed: 22-Nov-2017].

Література

[1] "The Clean Architecture," 8th Light. [Online]. Available: https://8thlight.com/blog/uncle-bob/2012/08/13/the-cleanarchitecture.html. [Accessed: 12-Sep-2017].

[2] "Guide to App Architecture," Android Developers, 26-May-2017. [Online]. Available: https://developer.android.com/topic/libraries/architecture/guide.html. [Accessed: 12-Sep-2017].

[3] “Заблуждения Clean Architecture,” / Блогкомпании MobileUp / Хабрахабр. [Online]. Available: https://habrahabr.ru/company/mobileup/blog/335382/. [Accessed: 12-Sep-2017].

[4] “Создание архитектуры программы или как проектировать табуретку,” / Хабрахабр. [Online]. Available: https://habrahabr.ru/post/276593/. [Accessed: 12-Sep-2017].

[5] "Architecting Android...The clean way?," Fernando Cejas, 02-Sep-2014. [Online]. Available: https:/fernandocejas.com/2014/09/03/architecting-android-the-clean-way/. [Accessed: 12-Sep-2017].

[6] "Разбираемся с новыми архитектурными компонентами в Android," / Блог компании Google / Xaбрахабр. [Online]. Available: https://habrahabr.ru/company/google/blog/330208/. [Accessed: 12-Sep-2017].

\title{
THE MODEL FOR POWER EFFICIENCY ASSESSMENT OF CONDENSATION HEATING INSTALLATIONS
}

\author{
D. Kovalchuk ${ }^{1}$, A. Mazur ${ }^{2}$, S. Hudz ${ }^{3}$ \\ ${ }^{1,2,3}$ Odessa National Academy of food technologies \\ ${ }^{1}$ Postgraduate, ${ }^{2}$ Assistant professor, ${ }^{3}$ Master student \\ ORCID: ${ }^{1} 0000-0003-0549-5244$ \\ E-mail: ${ }^{1}$ radiolomaster@gmail.com, ${ }^{2}$ mazur.av.ua@gmail.com, ${ }^{3}$ sergogudz@gmail.com
}

Copyright (C 2017 by author and the journal “Automation technological and business - processes". This work is licensed under the Creative Commons Attribution International License (CC BY). http://creativecommons.org/licenses/by/4.0/
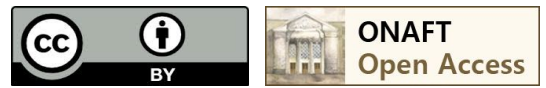

Abstract: The main part of heating systems and domestic hot water systems are based on the natural gas boilers. For increasing the overall performance of such heating system the condensation gas boilers was developed and are used. However even such type of boilers don't use all energy which is released from a fuel combustion. The main factors influencing the lowering of overall performance of condensation gas boilers in case of operation in real conditions are considered. The structure of the developed mathematical model allowing estimating the overall performance of condensation gas boilers $(C G B)$ in the conditions of real operation is considered. Performace evaluation computer experiments of such CGB during a heating season for real weather conditions of two regions of Ukraine was made. Graphic dependences of temperature conditions and heating system effectiveness change throughout a heating season are given. It was proved that normal CGB does not completely use all calorific value of fuel, thus, it isn't effective. It was also proved that the efficiency of such boilers significantly changes during a heating season depending on weather conditions and doesn't reach the greatest possible value. The possibility of increasing the efficiency of CGB due to hydraulic division of heating and condensation sections and use of the vapor-compression heat pump for deeper cooling of combustion gases and removing of the highest possible amount of thermal energy from them are considered. The scheme of heat pump connection to the heating system with a convenient gas boiler and the separate condensation economizer allowing to cool combustion gases deeply below a dew point and to warm up the return heat carrier before a boiler input is provided. The technological diagram of the year-round use of the heat pump for hot water heating after the end of heating season, without gas use is offered. 
Keywords: condensation gas boiler, efficiency, heat pump.

\section{Introduction}

Recently in case of design of residential and industrial buildings there is a tendency to use of the independent heatgenerating aggregates for heating systems and hot water-supply. The main parts of such aggregates are built on the basis of the gas boilers (GB). The maximum efficiency of normal GB calculated from the higher (full) calorific value of fuel fluctuates in the range of $78-85 \%$ [1,2]. The specific heat wastes of independent GB calculated from the higher (full) calorific value of fuel usually make $15-22 \%$, including:

- heat losses with the leaving flue gases to - to $18 \%$;

- the losses associated with incomplete combustion of fuel - 1-2\%;

- the losses to the environment associated with imperfection of heat insulation of GB $-2-3 \%$.

To increase the efficiency of heating systems the condensation gas boilers (CGB) were developed and are issued by the industry. They are equipped with the condensation heat exchanger which is removing additional heat from combustion gases, cooling them and partially condensing water vapor. The cost of CGB of the same power is normal 1.5-2 times higher than GVK. The maximum efficiency declared by vendors reaches $97 \%$. However as the cooling of combustion gases in CGB is carried out by the reverse heat carrier, amount of addition removed heat, and the overall performance of all installation will depend on the temperature of the reverse heat carrier. The lover temperature of the heat carrier coming from the reverse pipeline is, the higher efficiency of CGB with other equal conditions is. The temperature of the reverse heat carrier is nonconstant. It can change in the range from 22 to $60{ }^{\circ} \mathrm{C}$ and depends on the type of heating system, operation mode and ambient temperature. Heating system control is usually weather-depended, i.e. temperature of the heat carrier given to the heating system varies depending on ambient temperature. Therefore, also the temperature of the heat carrier coming from the reverse pipeline will change, and together with it the overall performance of CGB and all system in general will change. In this regard the maximum efficiency values of such boilers declared by vendors can be reached not in all modes of real operation.

\section{Main part}

For evaluation of overall performance of CGB in the real operation conditions during a heating season the mathematical model calculating the main modes and energetic values when CGB operates as a part of heating system with use of archive of real weather conditions data in any region of the country for the selected period was developed and realized in the simulation environment of Matlab Simulink. The skeleton diagram of model is provided on a figure 1. It includes:

- the unit calculating the required heat carrier temperature in the supply pipeline - calculates the necessary temperature of the heat carrier in the supply pipeline of the heating system depending on the ambient temperature and the desired indoor temperature (as a part of a subsystem "House");

- the model of a heat energy consumer - calculates the consumed thermal power and temperature of the heat carrier in the reverse pipeline depending on the ambient temperature, air humidity, speed and the direction of wind, the desired indoor temperature, temperature and the flow rate of the heat carrier in the supply pipeline (a subsystem "House");

- the CGB model - calculates temperature of the leaving gases, condensation section power, the instantaneous efficiency of CGB depending on the temperature of the reverse heat carrier of heating system and a finite difference of temperatures on the condenser and also average efficiency on the reference interval of time (a subsystem "Performance").

The main input variables for model are ambient temperature and the flow rate of the heat carrier. The output variables are: water temperature in the reverse pipeline, the consumed heat power, efficiency of CGB, fuel consuming. All variables dynamically change throughout a heating season. The model also calculates average efficiency of a system during a heating season.

On a figure 2 the diagram of a subsystem "House" and on a figure 3 the skeleton diagram of subsystem "Performance" is shown.

The temperature, which the combustion gases will be cooled to, depends on the temperature of the reverse heat carrier. In case of the effective condenser heat exchanger the loss of a temperature will make 5-7 degrees. The diagram of dependence of CGB efficiency with such condenser heat exchanger from the temperature of the leaving combustion gases, received as a result of simulation by means of a subsystem "Performance" under existing conditions is shown in a figure 4 . On a diagram it is possible to select 2 sections. On a section 1 when the combustion gases temperature is lowering the efficiency changes slightly. It is connected to the fact that there is no condensation of water vapor yet. On a section 2 the efficiency begins to grow promptly, because of additional heat separation in case of condensation of water vapor.

From the simulation results it is obvious that for the maximum energetic efficiency of CGB achievement it is necessary to strive to provide the minimum possible heat carrier temperature at the intake of condensation section. However in real conditions when heating systems operates with a temperature changing in a wide range, this task conflicts to requirements of vendors - to provide the flow rate of the heat carrier through CGB up to standard. This contradiction becomes aggravated when CGB is used not only for needs of heating but also for domestic hot water (DHW). At the same time heat carrier temperature on the output of CGB shall be $60-80^{\circ} \mathrm{C}$ and its flow rate unlike heating system can change almost instantaneous and in a wide range. It forces designers to apply different solutions with submission of a part of the heat carrier from CGB output on its input (hydroarrows, three-way valves, etc.) for coordination of thermal and hydraulic modes of the CGB, the DHW system and the 
heating system. It leads to the heat carrier temperature increasing at the input of CGB and respectively to lowering of its efficiency.

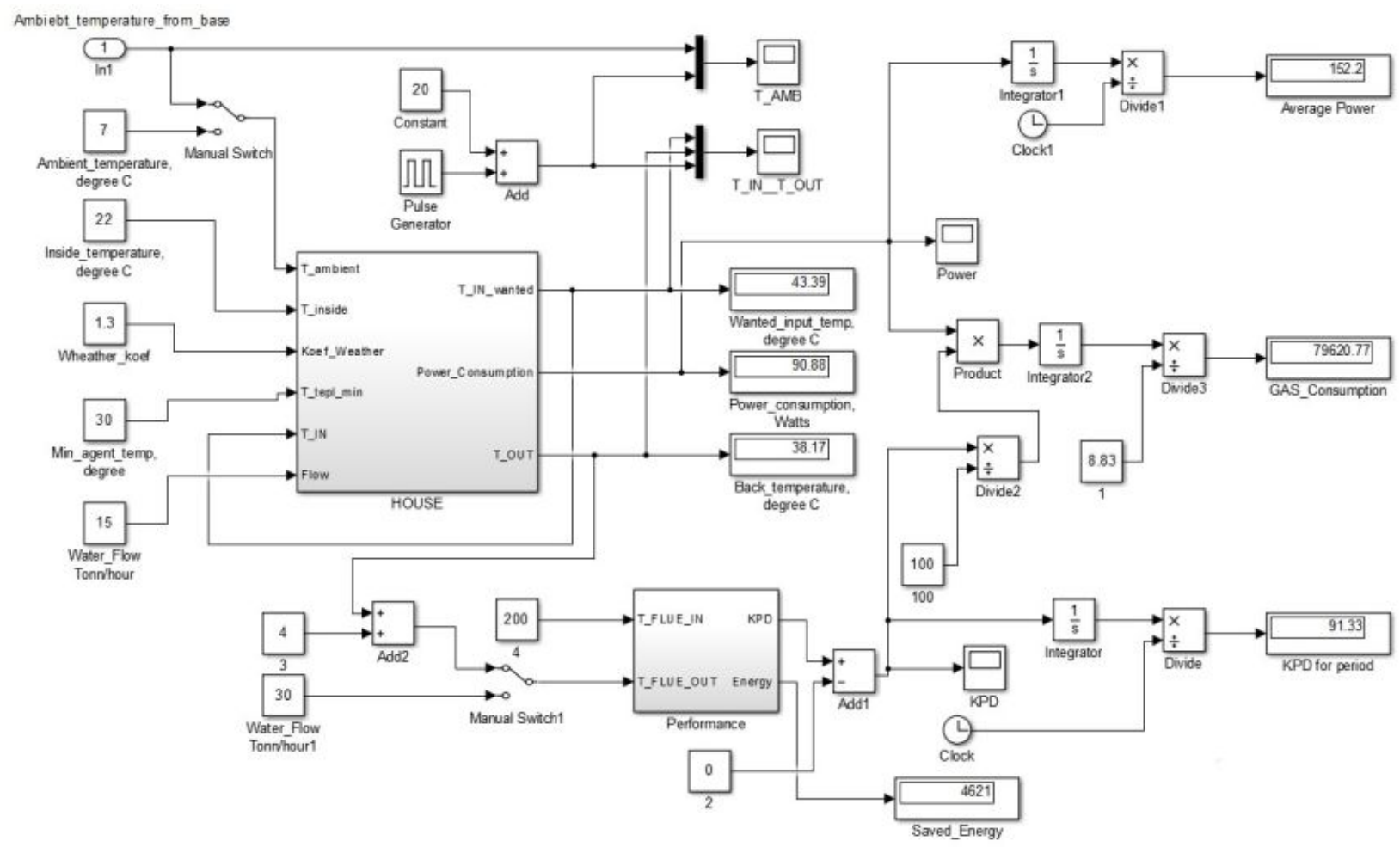

Fig. 1 - The block diagram of model for the CGB efficiency evaluation

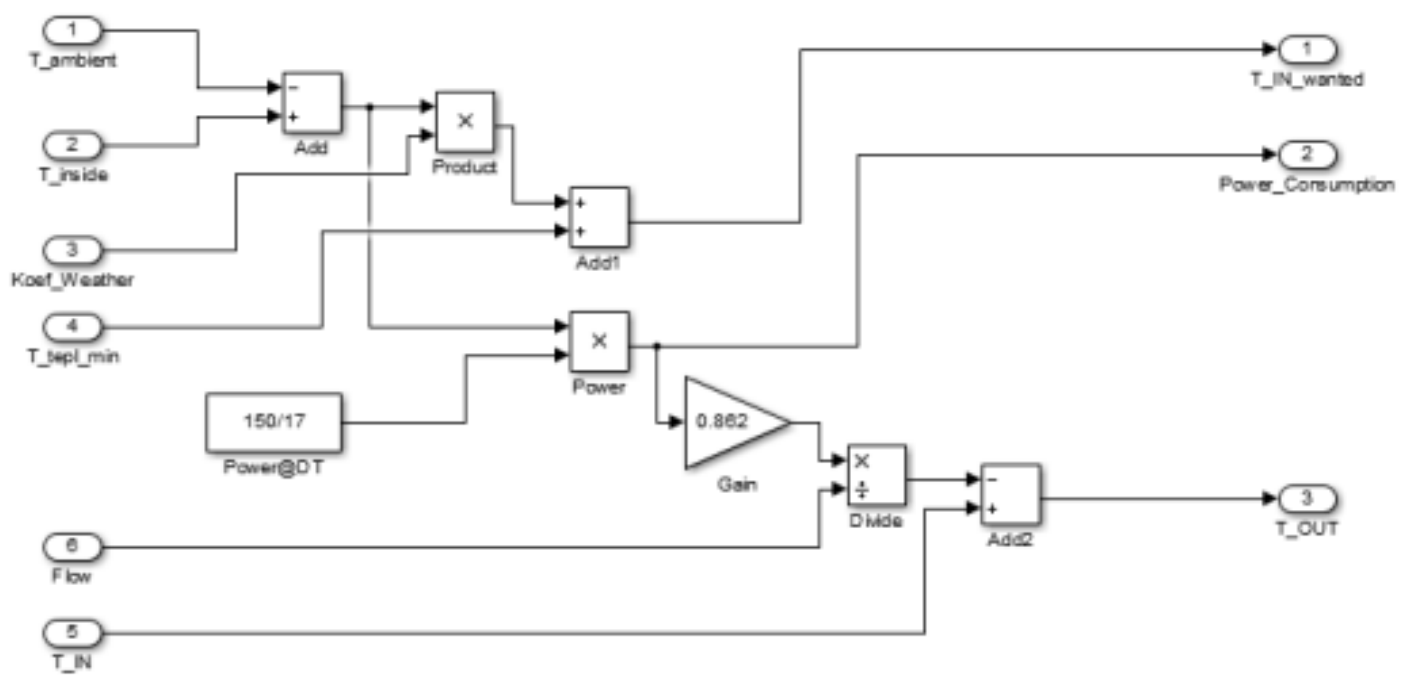

Fig. 2 - A subsystem "House"

For an evaluation of overall performance of CGB by means of the developed model the weather data archive from a digital resource [5] for two cities of Ukraine - Odessa and Kiev, during 2008-2016 was used. From this archive the data about ambient temperature, humidity, speed and the direction of wind during heating seasons (from October 1 to April 31) with a change step 
of 3 hours were selected. These data were imported to model in the form of an array and were used as input variables for simulation.

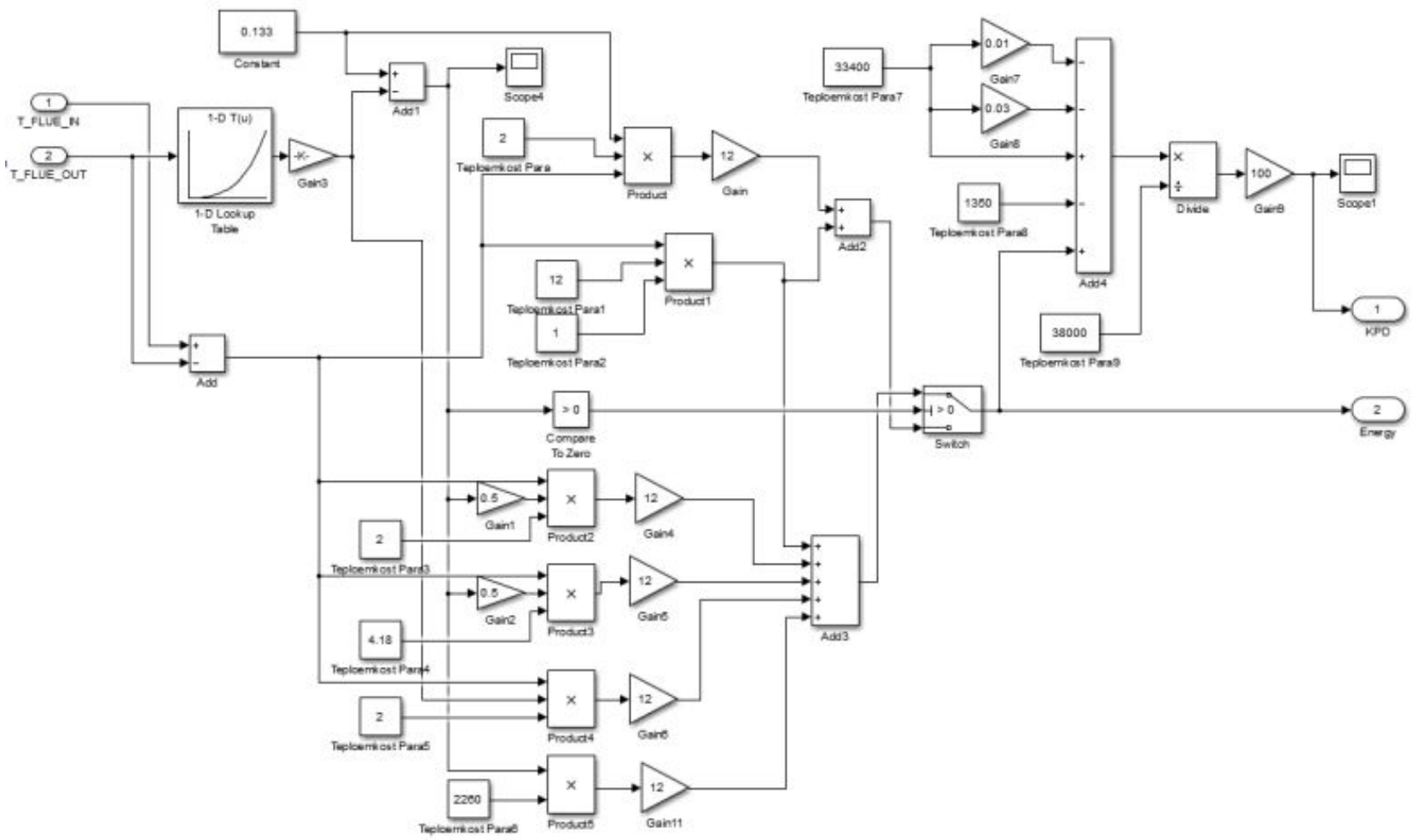

Fig. 3 - A subsystem "Performance"

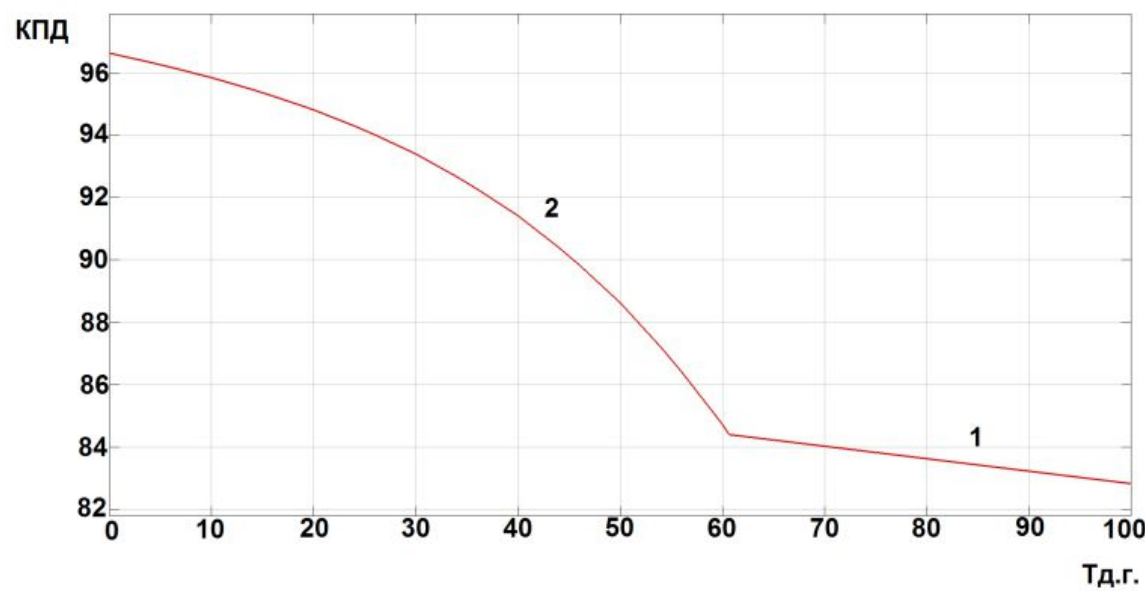

Fig. 4 - The diagram of installation efficiency change depending on the leaving gases temperature

\section{Results of experiments}

The experiment was made for weather data for two cities of Ukraine - Odessa and Kiev, for heating seasons 2014-2015, 2013-2014, 2012-2014. The values of average efficiency of CGB calculated from the upper combustion heat of fuel received as a result of simulation are given in tab. 1 .

Table 1 - Annual average efficiency of CGB

\begin{tabular}{|l|l|l|}
\hline Season & Odessa & Kiev \\
\hline $2012-2013$ & 91,5 & 90,4 \\
\hline $2013-2014$ & 91,6 & 90,8 \\
\hline $2014-2015$ & 91,3 & 90,7 \\
\hline
\end{tabular}


As an example we will consider the received simulation results based on weather archive data for Odessa for 2014-2015 heating season. In a figure 5 the diagram of ambient temperature change throughout a heating season of 2014-2015 which was an input variable for simulation is provided. In a figure 6 the diagram of the heat carrier temperatures in the supply and reverse pipelines change throughout this heating season received as a result of simulation is provided. In a figure 7 the diagram of CGB efficiency change during a heating season calculated from the upper calorific value is provided. In the upper part of the diagram there is shown by direct lines what levels of the CGB efficiency could be if a heat carrier temperature in the reverse pipeline was 25 and 30 of ${ }^{\circ} \mathrm{C}$.

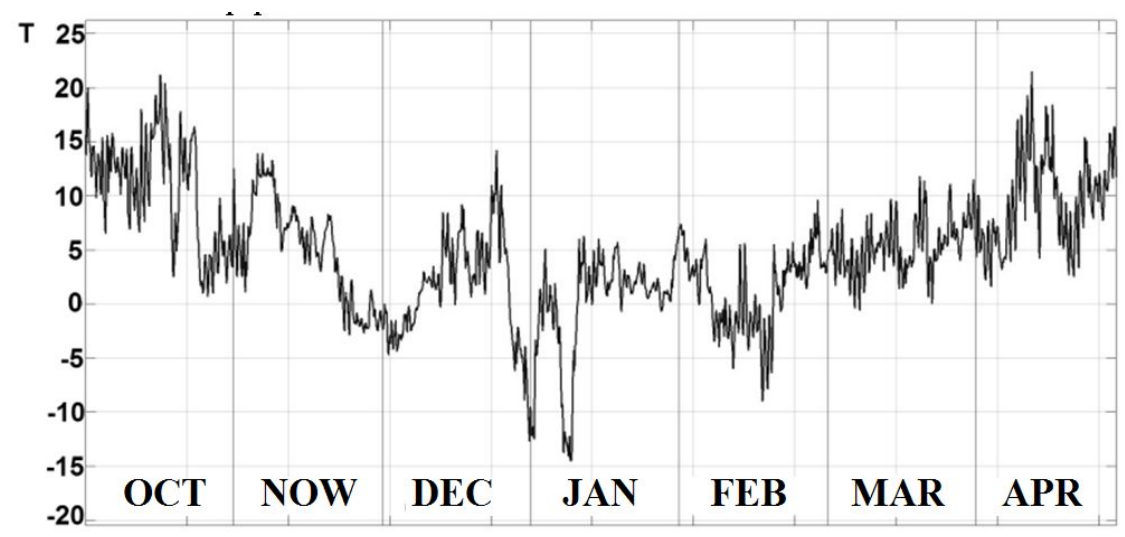

Fig. 5 - Ambient temperature change during a heating season

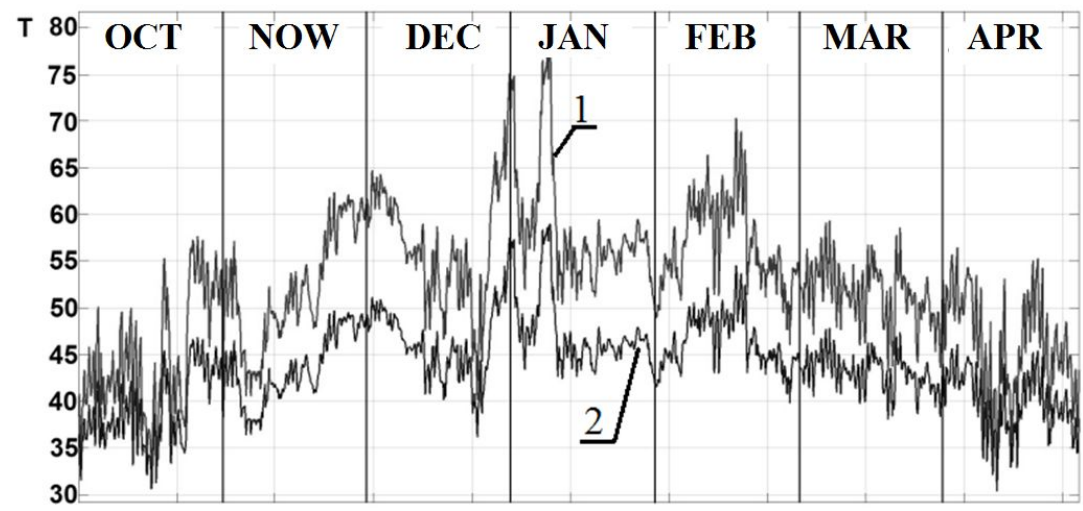

Fig. 6 - Change of the heat carrier temperatures in the supply (1) and the return (2) pipelines during a heating season

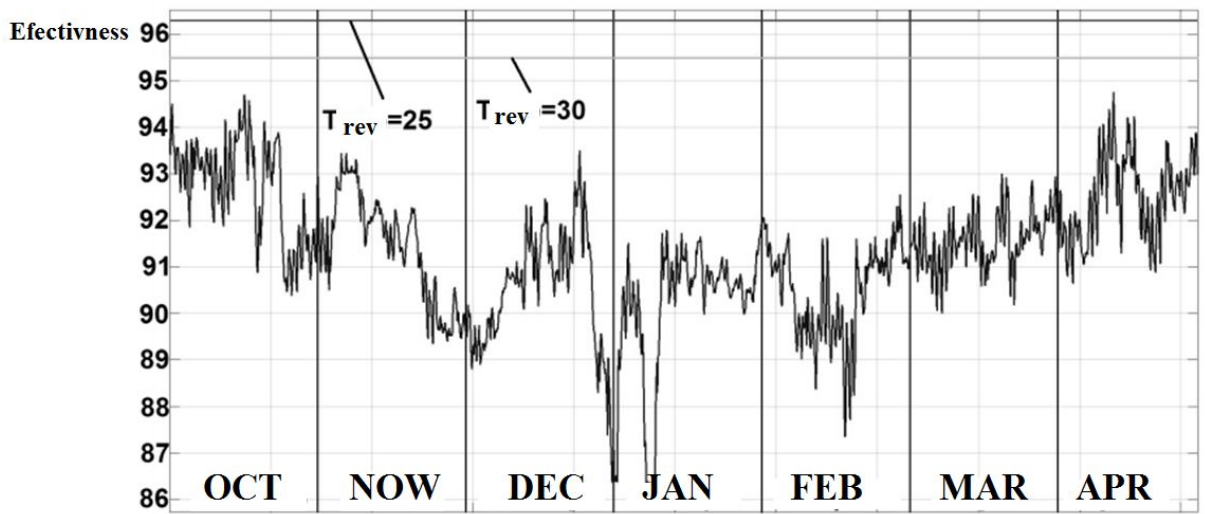

Fig. 7 - Change of CGB efficiency during a heating season

The simulation results have been confirmed experimentally. During the heating season 2014-2015 in Odessa it was observed the autonomous gas boiler working as a part of heating system and domestic hot water of an apartment housing estate. In the $1000 \mathrm{~kW}$ power heating system equipped with highly effective CGB C230 Eco of the French firm "De Dietrich" 
daily registration of the consumed gas and the condensed water vapor (condensate) amount was carried out. Results of observations have shown that during the season the amount of the condensed water vapor per $1 \mathrm{~m}^{3}$ of the burned gas has averaged only $326 \mathrm{~g}$ from the possible $1500 \mathrm{~g}$. It means that the efficiency of CGB installed in the heating system average for the heating season calculated from the upper calorific value has amounted less than $88 \%$ and it at the maximum efficiency declared by the producer reaching $97 \%$. Results of these observations practically coincide with results of simulation that confirms adequacy to the developed model.

\section{Discussions}

From the results of experiments it follows that CGB though is more effective than usual GB, but in the conditions of real operation it also not completely uses all calorific value of fuel because the temperature of the return heat carrier can change during a heating season in the range from $25{ }^{\circ} \mathrm{C}$ to $55^{\circ} \mathrm{C}$ and it leads to change of CGB efficiency in range from $97 \%$ to $85 \%$ respectively. The efficiency of the heatgenerating installation with a condensation boiler can be increased by supplying the heat carrier with lower temperature into the condensation section. In the figure 7 straight lines shown what would the efficiency of system be if a heat carrier temperature on a condensation section entrance will be at the level of 25 and 30 degrees. Thus, it is possible to draw a conclusion that even the most effective KGVK during the work in actual practice doesn't gather additionally 7-8 percent to the maximum values declared by producers.

For overall performance of CGB increasing there is a sense to take measures for decreasing the temperature of the heat carrier used for cooling of combustion gases that won't absolutely be coordinated, and sometimes contradicts recommendations of producers about integration of CGB into the heating system - providing the heat carrier flow rate through CGB which set by them. This contradiction goes deeper when CGB at the same time is used for the domestic hot water supply (DHWS). At the same time the heat carrier temperature at its output has to be $60-70{ }^{\circ} \mathrm{C}$ and the required flow rate unlike heating system can change almost instantly in wide range of values. In such cases for coordination of temperature and hydraulic conditions of the CGB, DHWS system and heating system requires the use of different mixing devices (hydraulic separator, three-running valves, etc.) giving a part of the CGB output heat carrier on its input that leads to the temperature increasing on its input and, respectively, to additional essential decrease in efficiency of CGB in the conditions of real operation.

One of the ways of permission of some part of these contradictions is the division of hydraulic schemes of section of "condensation" and section of "reheating" in CGB that practically means a possibility of application of usual inexpensive GB and the condensation economizer (CE) for cooling of combustion gases. This scheme provides supplying the heat carrier to KE input with minimum possible temperature directly from the return pipeline of heating system before the admixture system of the heat carrier from GB output. Such decision allows to reach the greatest possible efficiency in these conditions without breaking the GB hydraulic mode at the same time and becomes more attractive for increasing the power of such CGB.

The next step could be taking measures for ensuring lower temperature of the heat carrier on the condensation section entrance. One of the variants of this task solution is use of the heat pump. In the figure 8 the scheme of connection of the heat pump to the heatgenerating installation with a condensation gas boiler is shown. The heat pump is equipped with two liquid heat exchangers ("Water-water"). The contour of the evaporator is connected to the condenser of combustion gases - special heat exchanger cooling combustion gases. The contour of the condenser is connected to the return pipeline of heating system, and warms up the return heat carrier, before it is given to the GB input. Having provided optimum control of the heat pump operating modes, it is possible an essential increase of power efficiency of all heatgenerating installation (HGI) due to the deeper utilization of heat of combustion gases and transfer of this energy in a heating contour.

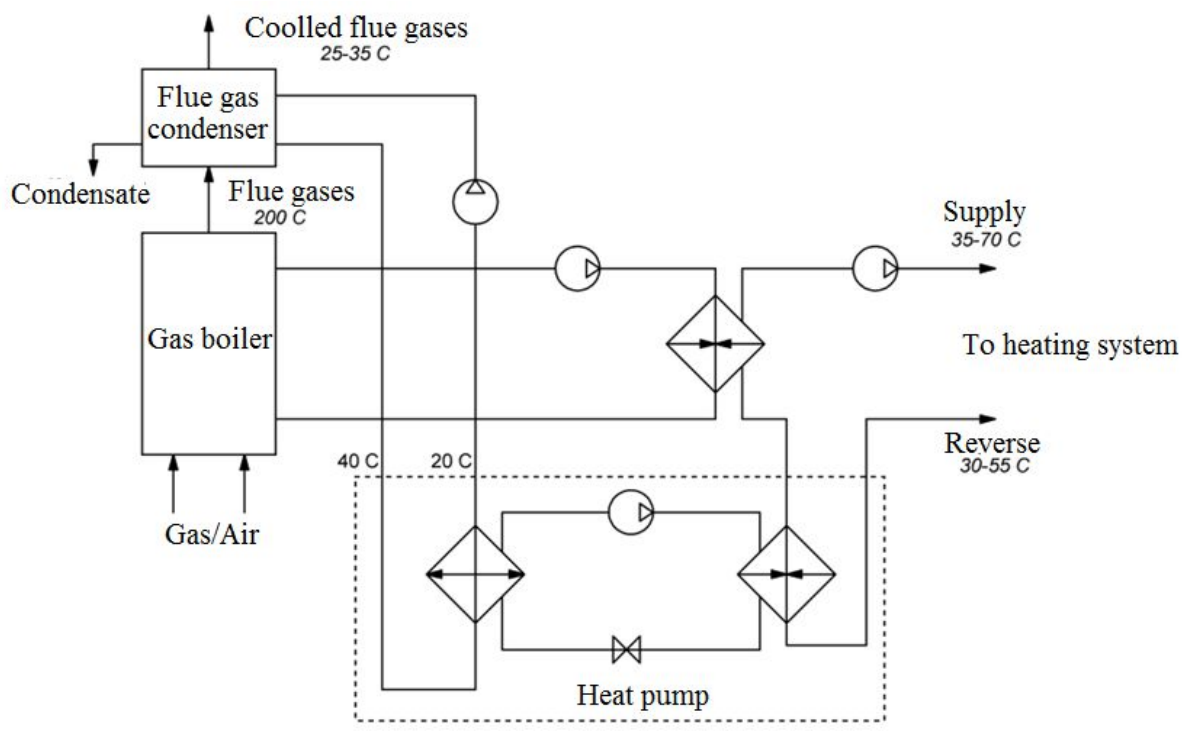

Fig. 8 - Scheme of connection of the heat pump to the CGB 
During the summer period use of the heat pump without use of GB for heating of domestic hot water is possible what will reduce payback periods of capital investments almost twice. For this purpose the heat pump is equipped with additional air heat exchanger taking heat for water heating from atmospheric air.

\section{Conclusions}

Condensation gas boilers during the work in real conditions as a part of heating system don't reach the efficiency declared by producers that is confirmed by results of the experiments provided by means of the developed mathematical model and observation of the real condensation boiler working in Odessa. It confirms the adequacy of the developed model. For ensuring deep utilization of the heat of combustion gases and achievement of the maximum power efficiency it is necessary to divide hydraulically the heating section and the condensation section of CGB and to cool the heat carrier circulating in condensation section by means of the vapor-compression heat pump. For reduction of payback periods of the capital investments it is possible to use the heat pump without GB for domestic hot water during the summer period after the end of a heating season. For ensuring the greatest possible power efficiency of such heating system it is necessary to develop the automatic control system providing optimum control of the heat pump and all system in general.

\section{References}

[1] V. M. Panarin [V. M. Panarin, O. A. Dabdina], "Kontrol' ehnergo- i teplopoter' na ob"ektah, vyrabatyvayushchih teplovuyu ehnergiyu" in Materialy Vserossijskoj nauchno-prakticheskoj konferencii "Molodye uchyonye $v$ reshenii aktual'nyh problem nauki", 2012, pp. 174-176.

[2] M. A. Rajsh, "Polnoe ispol'zovanie teploty sgoraniya topliva v promyshlennyh kotel'nyh", Akva-Term, no. 3(43), pp. 20-24, 2008.

[3] N. A. Petrikeeva [N. A. Petrikeeva et al.], "Ispol'zovanie polnoj teploty sgoraniya topliva v kotel'nyh ustanovkah", Inzhenernye sistemy $i$ sooruzheniya, vol. 2, no. 4, pp. 76-80, 2014.

[4] A. V. Efimov [A. V. Efimov, A. L. Goncharenko], "Matematicheskaya model' sistemy "kotel-teploutilizator"”, Vestnik NTU "HPI": sbornik nauchnyh trudov, no. 21, pp. 76-87, 2010.

[5] D. A. Kovalchuk [D. A. Kovalchuk, A. V. Mazur, S. S. Hudz], "Ocenka ehnergeticheskoj ehffektivnosti gazovogo kondensacionnogo vodogrejnogo kotla kak ob"ekta upravleniya”, Naukovi praci ONAHT, no. 80, vol. 2, pp. 95-98, 2017.

[6] F. I. Molochko, ”Ustrojstvo dlya utilizacii teploty dymovyh gazov”, BY Patent 18256, June 30, 2014.

[7] Raspisanie pogodyi [Online]. Available at: http://www.rp5.ua/

\section{Література}

[1] Панарин В. М., Дабдина О. А. Контроль энерго- и теплопотерь на оъектах, вырабатывающих тепловую энергию // Молодые учёные в решении актуальных проблем науки: материалы Всероссийской научно-практической конференции, 2012. - С. 174-176.

[2] Райш М. А. Полное использование теплоты сгорания топлива в промышленных котельных / Аква-Терм, № 3(43), 2008. - С. 20-24.

[3] Петрикеева Н. А. и др. Использование полной теплоты сгорания топлива в котельных установках / Инженерные системы и сооружения, том 2, №4, 2014. - С. 76-80.

[4] Ефимов А. В., Гончаренко А. Л. Математическая модель системы "котел-теплоутилизатор" / Вестник НТУ "ХПИ": сборник научных трудов, № 21, 2010. - С. 76-87.

[5] Ковальчук Д. А., Мазур А. В., Гудзь С. С. Оценка эннергетической эффективности газового конденсационного водогрейного котла как объекта управления / Наукові праці ОНАХТ, № 80, том 2, 2017. - С. 95-98.

[6] Молочко Ф. И. Устройство для утилизации теплоты дымовых газов / Патент РБ 18256, 30 Июня, 2014.

[7] Расписание погоды // Режим доступа: - http://www.rp5.ua/ 